\title{
FLUDARABINE, CYTARABINE, GRANULOCYTE COLONY-STIMULATING FACTOR, AND IDARUBICIN (FLAG-IDA) FOR THE TREATMENT OF CHILDREN WITH POOR-PROGNOSIS ACUTE LEUKEMIA: The Hacettepe Experience
}

Betul Tavil, Selin Aytac, Yasemin Isık Balcı, Sule Unal, Barıs Kuskonmaz, Sevgi Yetgin, Aytemiz Gurgey, Murat Tuncer, Fatma Gumruk, Duygu Uckan \& Mualla Cetin

To cite this article: Betul Tavil, Selin Aytac, Yasemin Isık Balcı, Sule Unal, Barıs Kuskonmaz, Sevgi Yetgin, Aytemiz Gurgey, Murat Tuncer, Fatma Gumruk, Duygu Uckan \& Mualla Cetin (2010) FLUDARABINE, CYTARABINE, GRANULOCYTE COLONY-STIMULATING FACTOR, AND IDARUBICIN (FLAG-IDA) FOR THE TREATMENT OF CHILDREN WITH POOR-PROGNOSIS ACUTE LEUKEMIA: The Hacettepe Experience, Pediatric Hematology and Oncology, 27:7, 517-528, DOI: $10.3109 / 08880018.2010 .493578$

To link to this article: https://doi.org/10.3109/08880018.2010.493578

\section{Published online: 02 Aug 2010.}

\section{Submit your article to this journal 주}

Llll Article views: 798

Q View related articles ¿ك

ef

Citing articles: 8 View citing articles $\longleftarrow$ 


\title{
Article
}

\section{FLUDARABINE, CYTARABINE, GRANULOCYTE COLONY-STIMULATING FACTOR, AND IDARUBICIN (FLAG-IDA) FOR THE TREATMENT OF CHILDREN WITH POOR-PROGNOSIS ACUTE LEUKEMIA: The Hacettepe Experience}

\author{
Betul Tavil, MD, Selin Aytac, MD, Yasemin Isık Balcı, MD, Sule Unal, MD, \\ Barıs Kuskonmaz, MD, Sevgi Yetgin, MD, Aytemiz Gurgey, MD, Murat \\ Tuncer, MD, Fatma Gumruk, MD, Duygu Uckan, MD, and Mualla Cetin, MD \\ - Pediatric Hematology Unit, Ihsan Dogramacı Children's Hospital, Hacettepe University \\ Faculty of Medicine, Ankara, Turkey
}

\begin{abstract}
$\square \quad$ Fludarabine, cytarabine, granulocyte colony-stimulating factor (G-CSF), and idarubicin (FLAG-IDA) regimen has been proven to be a potentially useful chemotherapy regimen for relapsed or poor-prognosis childhood leukemia. The aim of the study was to evaluate complete remission (CR) rate, toxicity, and overall survival of children with poor-prognosis acute leukemia who received the FLAG-IDA regimen. Furthermore, the authors investigated the children who achieved CR following FLAG-IDA treatment regarding their eligibility for allogeneic hematopoietic stem cell transplantation (HSCT). Between January 2002 and April 2007, 25 children with poor-prognosis acute leukemia were treated with FLAG-IDA regimen in our center. Of the 25 children (16 AML, 9 ALL) with poor-prognosis acute leukemia, 7 (28.0\%) received 1 cycle, 17 (68.0\%) received 2 cycles, and 1 (4\%) received 3 cycles of FLAG or FLAG-IDA regimen. After 44 cycles of FLAG-IDA or FLAG regimen, 10/25 (40\%) children were nonresponders, 15/25 (60.0\%) showed CR. Five (20\%) of these patients in CR who underwent allogeneic HSCT are still in remission. The remaining 20 (80.0\%) children were lost due to infection or relapse of the primary diseases. The overall survival of patients who are still alive and underwent allogeneic HSCT (mean: 40.6 4 4.7, median: 40, range: 34-46 months) was longer than that of patients (mean: $5.5 \pm 4.3$, median: 4, range: $1-15$ months) who did not undergo allogeneic HSCT. The CR rate was quite high in the present study using the FLAGIDA regimen, and the authors believe this regimen is a possible option prior to allogeneic HSCT in children with poor-prognosis acute leukemia.
\end{abstract}

Keywords acute leukemia, children, FLAG-IDA regimen, poor prognosis

Received 6 December 2009; Accepted 4 May 2010.

The authors thank TUBA (The Turkish Academy of Sciences) for their support.

Address correspondence to Mualla Cetin, Pediatric Hematology Unit, Ihsan Dogramacı Children's Hospital, Hacettepe University Faculty of Medicine, 06100-Sihhıye, Ankara, Turkey. E-mail: mcetin@hacettepe.edu.tr 
The prognosis of relapsed and/or primary resistant acute leukemia (acute lymphoblastic leukemia [ALL] and acute myeloblastic leukemia [AML]) and secondary AML is quite poor, and an effective reinduction regimen for these types of leukemias is quite rare. Allogeneic and autologous hematopoietic stem cell transplantation (HSCT) offers a chance for longterm survival in these childhood cases with poor-prognosis acute leukemia. The fludarabine, cytarabine, granulocyte colony-stimulating factor (G-CSF), and idarubicin (FLAG-IDA) regimen has been proven to be a potentially useful chemotherapy regimen for relapsed or poor-prognosis childhood leukemia [1-3].

Fludarabine (9- $\beta$-D-arabinofuranosyl-2 fluoroadenine) is a synthetic purine analogue. Its antitumor activity is conducted through inhibition of DNA and RNA synthesis, DNA and RNA polymerases, DNA primase, DNA ligase, and ribonucleated reductase, and by potentiation of deoxycytidine kinase activity. It also induces apoptosis and potentiates the activity of cytosine arabinoside (Ara-C). High-dose Ara- $\mathrm{C}$ is one of the most effective drugs in the treatment of acute leukemia. The efficacy of Ara-C has been related to the higher intracellular concentration of the active metabolite Ara-C 5'-triphosphate (Ara-CTP). An increase in intracellular Ara-CTP can be achieved upon pretreatment with fludarabine. Administration of fludarabine prior to Ara-C may enhance the cytotoxicity and clinical efficacy of Ara-C [4]. The addition of G-CSF to the FLAG regimen has shortened the duration of neutropenia and reduced infection rates following the chemotherapy regimen. Furthermore, G-CSF increases the efficacy of the chemotherapeutic agents by recruitment of leukemic cells in to the S-phase. IDA, an anthracycline, has also been combined with the FLAG regimen to increase antileukemic activity [1-3].

The FLAG regimen has been extensively used in adult patients with poorprognosis acute and chronic leukemia since 1996 [5, 6]. However, a series of children with poor-prognosis acute leukemia treated with the FLAG-IDA regimen has rarely been reported in the literature [1-3]. FLAG-IDA has been used in relapsed and/or primary resistant acute leukemia (ALL and AML) and secondary AML cases in Hacettepe University Faculty of Medicine, Pediatric Hematology Unit, since 2002. The aim of the study was to evaluate the complete remission (CR) rate, toxicity, and overall survival of children with poor-prognosis acute leukemia who received the FLAG-IDA regimen. Furthermore, we aimed to investigate the children who achieved CR following FLAG-IDA treatment regarding their eligibility for allogeneic HSCT.

\section{MATERIAL AND METHODS}

Between January 2002 and April 2007, 25 children (11 [44\%] girls and $14[56 \%]$ boys) with poor-prognosis acute leukemia were treated with the 
FLAG-IDA regimen in our center. The median age of the children was 12 years (range: 2-17 years). Informed written consent was obtained from all of the children and/or parents before administration of the regimen. Of these 25 children with poor-prognosis acute leukemia, 9 children were ALL ( 2 resistant ALL; 7 second- or third-relapsed ALL) and 16 children were AML (3 resistant AML; 8 first-relapsed AML; 5 secondary AML) at the time of FLAG-IDA administration. The patient group was heterogeneous as to the extent of pretreatment chemotherapy, and all patients were heavily pretreated with a variety of chemotherapeutic agents.

All 25 children had bone marrow infiltration and 7 had additional extramedullary disease at the time of FLAG-IDA administration. Among the 7 children with extramedullary disease, 2 had central nervous system (CNS) relapse, 2 had bone involvement, 1 had testicle relapse, 1 had orbital involvement, and 1 had orbital and CNS involvement.

Cardiac evaluation was performed by echocardiography and left ventricle ejection fraction (EF) $>60 \%$ was the eligibility criterion for all of the children before administration of the regimen. Renal and hepatic functions were also evaluated before the FLAG-IDA regimen. According to the National Cancer Institude (Common Toxicity Criteria), the patients with transaminases (serum oxaloacetic transaminase [SGOT], serum glutamic pyruvic transaminase $[\mathrm{SGPT}])>2.5 \times$ normal and creatinine $>1.5 \times$ normal were not received FLAG-IDA regimen [7].

\section{Routine Procedures and Prophylactic Agents}

The implantation of a central venous catheter or a previously implanted port was necessary before administration of the regimen. Hydration, alkalinization, and allopurinol were advised for patients at risk of tumor lysis syndrome. Corticosteroid eye drops starting prior to the first Ara-C infusion were given every 6 hours and discontinued 12 hours after the last Ara-C infusion.

An antiemetic drug (ondansetron or granisetron) was used throughout the chemotherapy regimen. Trimethoprim-sulfamethoxazole (TMP-SMX) at a dosage of $5 \mathrm{mg} / \mathrm{kg}$ body weight daily, 3 times a week, and fluconazole at a dosage of $3 \mathrm{mg} / \mathrm{kg}$ body weight daily were administered as antibacterial and antifungal prophylaxis, respectively.

\section{Treatment Regimen}

The FLAG-IDA regimen includes $30 \mathrm{mg} / \mathrm{m}^{2} /$ day of fludarabine by a 30-minute intravenous infusion daily for 4 consecutive days (days 1-4); $2000 \mathrm{mg} / \mathrm{m}^{2} /$ day of Ara-C by a 3-hour intravenous infusion daily for 4 consecutive days (days 1-4), starting 4 hours after the beginning of fludarabine; and $12 \mathrm{mg} / \mathrm{m}^{2} /$ day IDA by a 1-hour intravenous infusion daily for 3 consecutive 
days (days 2-4), starting 1 hour prior to Ara-C infusion. G-CSF was administered at a dosage of $400 \mu \mathrm{g} / \mathrm{m}^{2} /$ day from day 0 to the day of absolute neutrophil count of $>1.0 \times 10^{9} / \mathrm{L}$.

Of the total 25 children with poor-prognosis acute leukemia, 7 (28.0\%) children received 1 cycle, $17(68.0 \%)$ received 2 cycles, and 1 (4\%) received 3 cycles of FLAG or FLAG-IDA regimen. Among the total of 44 cycles of the regimen, $35(79.5 \%)$ cycles were administered as FLAG-IDA and $9(20.5 \%)$ cycles were administered as FLAG regimen without IDA. When cardiotoxicity was observed on echocardiography after the first FLAG-IDA regimen, only FLAG regimen was allowed to avoid further cardiotoxicity.

\section{Response Evaluation}

A bone marrow aspiration was performed after hematological recovery was maintained (absolute neutrophil count $>1.0 \times 10^{9} / \mathrm{L}$ and platelets $>50$ $\left.\times 10^{9} / \mathrm{L}\right)$. CR was defined as evidence of normal hematopoietic regeneration (absolute neutrophil count $>1.0 \times 10^{9} / \mathrm{L}$, platelets $>50 \times 10^{9} / \mathrm{L}$, and with $<5 \%$ marrow blasts) and partial remission (PR) was defined as reduction of marrow blasts to at least $50 \%$. A second cycle of FLAG-IDA was given as a consolidation phase of the treatment.

The clinical and laboratory characteristics of the patients are shown in Table 1.

\section{RESULTS}

A total of 44 courses were administered to 25 children. Characteristics, diagnosis, response to FLAG-IDA regimen, overall survival, and outcome of the patients are seen in Tables 1 and 2.

\section{Treatment Response}

After the first cycle of FLAG-IDA regimen, CR was achieved in 14/25 $(56.0 \%)$ and PR was achieved in $2 / 25(8.0 \%)$ children, whereas $9(36.0 \%)$ children were nonresponders. Eighteen $(72.0 \%)$ children received a second cycle of FLAG-IDA or FLAG regimen. Of these 18 children, 13 received the regimen as consolidation therapy; 2 partial responders and 3 nonresponders also received the regimen to achieve CR (Table 2). After the second cycle of the regimen $(n=18), 15$ children showed CR and 3 children were nonresponders (Table 2 ). Only $1(4.0 \%)$ child (Case 1 ) received a third cycle of FLAG regimen. This child had received 2 cycles of FLAG-IDA regimen because of refractory AML-M7, and CR was achieved after 2 cycles of the regimen. While awaiting allogeneic HSCT (he had human leukocyte antigen [HLA] 6/6 identical sibling donor), first relapse of AML-M7 occurred and administration of a third cycle of FLAG regimen was decided. CR could not be achieved after the third cycle, and other treatment options including 
TABLE 1 Characteristics of the Children With Poor-Prognosis Acute Leukemia

\begin{tabular}{|c|c|}
\hline Characteristics & $n$ \\
\hline$N$ & 25 \\
\hline Age (median, range) & 12 ( $2-17$ years $)$ \\
\hline Sex (female/male) & $11 / 14$ \\
\hline & $n \quad$ Survivors \\
\hline Diagnosis & \\
\hline AML & $5 / 16$ \\
\hline M0 & 1 \\
\hline M1 & 2 \\
\hline M2 & 3 \\
\hline M4 & 2 \\
\hline M4-eo & 1 \\
\hline M5 & 1 \\
\hline M7 & 1 \\
\hline Secondary AML (secondary to ALL) & 5 \\
\hline ALL & $0 / 0$ \\
\hline CALLA(+) B cell ALL & 8 \\
\hline T cell ALL & 1 \\
\hline Disease stage & \\
\hline Refractory ALL & 2 \\
\hline Second-relapse ALL & 5 \\
\hline Third-relapse ALL & 2 \\
\hline Refractory AML & 3 \\
\hline First-relapse AML & 8 \\
\hline Secondary AML & 5 \\
\hline
\end{tabular}

gemtuzumab ozogamicin (anti-CD 33 antibody) were tried and allogeneic HSCT could not be performed. He expired with relapse.

After all cycles of FLAG-IDA or FLAG regimen, 15/25 (60.0\%) children showed CR and 10/25 (40.0\%) children were nonresponders (Table 2).

\section{Recovery of the Bone Marrow After the Regimen}

G-CSF was used in all of the children with a median duration of 18 days (range: 12-44 days) for neutrophil recovery. The median duration of leukocyte recovery (total leukocyte count $>1 \times 10^{9} / \mathrm{L}$ ) was 24.5 days (range: 9-50 days), of neutrophil recovery (absolute neutrophil count $>0.5$ $\times 10^{9} / \mathrm{L}$ ) 25 days (range: 11-40 days), and of platelet recovery (platelet count $>20 \times 10^{9} / \mathrm{L}$ ) 22 days (range: $12-50$ days) for all the children who received FLAG-IDA or FLAG regimen. The median number of erythrocyte transfusions was 12 and of thrombocyte transfusions, 13 from the beginning of the regimen to the bone marrow recovery.

\section{Toxicity}

The mean follow-up duration was $13.2 \pm 12.6$ months (median: 6 , range: 1-48 months) for all patients. There was no acute neurological or renal 
TABLE 2 Characteristics, Diagnosis, Response to FLAG-IDA Regimen, Overall Survival, and Outcome of the Patients

\begin{tabular}{|c|c|c|c|c|c|}
\hline Patient & $\begin{array}{l}\text { Age/Sex at } \\
\text { FLAG-IDA ad- } \\
\text { ministration } \\
\text { (year) }\end{array}$ & Diagnosis & $\begin{array}{l}\text { Duration of } \\
\text { first remission }\end{array}$ & $\begin{array}{l}\text { Response to } \\
\text { FLAG-IDA }\end{array}$ & $\begin{array}{c}\text { Overall } \\
\text { survival/Outcome }\end{array}$ \\
\hline 1 & $16 / \mathrm{M}$ & $\begin{array}{l}\text { AML-M7, } \\
\text { refractory }\end{array}$ & 13 months & $\begin{array}{l}\text { 1st FLAG-IDA: } \\
\text { CR } \\
\text { 2nd FLAG-IDA: } \\
\text { CR (consolida- } \\
\text { tion) } \\
\text { 3rd FLAG: (after } \\
\text { relapse) No } \\
\text { response }\end{array}$ & $\begin{array}{l}15 \text { months/expired } \\
\text { with relapse }\end{array}$ \\
\hline 2 & $10 / \mathrm{M}$ & $\begin{array}{l}\text { AML secondary } \\
\text { to CALLA }(+) \\
\text { B cell ALL, } \\
\text { Refractory }\end{array}$ & 10 months & $\begin{array}{l}\text { 1st FLAG-IDA: } \\
\text { CR } \\
\text { 2nd FLAG-IDA: } \\
\text { CR (consolida- } \\
\text { tion) }\end{array}$ & $\begin{array}{l}12 \text { months/expired } \\
\text { with relapse }\end{array}$ \\
\hline 3 & $14 / \mathrm{F}$ & $\begin{array}{l}\text { AML-M1/first } \\
\text { relapse }\end{array}$ & - & $\begin{array}{l}\text { AlloHSCT } \rightarrow \\
\text { relaps } \\
\text { 1st FLAG: No } \\
\text { response }\end{array}$ & $\begin{array}{l}2 \text { months/expired } \\
\text { with infection }\end{array}$ \\
\hline 4 & $15 / F$ & $\begin{array}{l}\text { AML-M4/first } \\
\text { relapse }\end{array}$ & 8 months & $\begin{array}{l}\text { 1st FLAG-IDA: PR } \\
\text { 2nd FLAG: CR } \\
\text { AlloHSCT }\end{array}$ & $\begin{array}{l}12 \text { months/expired } \\
\text { with relapse }\end{array}$ \\
\hline 5 & $9 / \mathrm{M}$ & $\begin{array}{l}\text { CALLA }(+) \text { B } \\
\text { cell } \\
\text { ALL/second } \\
\text { relapse }\end{array}$ & - & $\begin{array}{l}\text { 1st FLAG-IDA: } \\
\text { No response }\end{array}$ & $\begin{array}{l}3 \text { months/expired } \\
\text { with infection }\end{array}$ \\
\hline 6 & $14 / \mathrm{F}$ & $\begin{array}{l}\text { CALLA }(+) \text { B } \\
\text { cell } \\
\text { ALL/second } \\
\text { relapse }\end{array}$ & - & $\begin{array}{l}\text { 1st FLAG: No } \\
\text { response }\end{array}$ & $\begin{array}{l}1 \text { months/expired } \\
\text { with infection }\end{array}$ \\
\hline 7 & $9 / \mathrm{M}$ & $\begin{array}{l}\text { AML-M4/first } \\
\text { relapse }\end{array}$ & 8 months & $\begin{array}{l}\text { 1st FLAG-IDA: } \\
\text { CR } \\
\text { AlloHSCT }\end{array}$ & $\begin{array}{l}12 \text { months/expired } \\
\text { with relapse }\end{array}$ \\
\hline 8 & $7 / \mathrm{M}$ & $\begin{array}{l}\text { AML-M4- } \\
\text { Eo/refractory }\end{array}$ & 14 months & $\begin{array}{l}\text { 1st FLAG-IDA: } \\
\text { CR } \\
\text { 2nd FLAG: CR } \\
\text { (consolida- } \\
\text { tion) } \\
\text { AlloHSCT }\end{array}$ & 34 months/alive \\
\hline 9 & $12 / \mathrm{M}$ & $\begin{array}{l}\text { CALLA }(+) \text { B } \\
\text { cell ALL/ } \\
\text { third relapse }\end{array}$ & 6 months & $\begin{array}{l}\text { 2nd FLAG-IDA: } \\
\text { CR }\end{array}$ & $\begin{array}{l}6 \text { months/expired } \\
\text { with infection }\end{array}$ \\
\hline 10 & $4 / \mathrm{F}$ & $\begin{array}{l}\text { T cell } \\
\text { ALL/second } \\
\text { relapse }\end{array}$ & - & $\begin{array}{l}\text { 1st FLAG-IDA: } \\
\text { No response }\end{array}$ & $\begin{array}{l}2 \text { months/expired } \\
\text { with infection }\end{array}$ \\
\hline
\end{tabular}


TABLE 2 Characteristics, Diagnosis, Response to FLAG-IDA Regimen, Overall Survival, and Outcome of the Patients (Continued)

\begin{tabular}{|c|c|c|c|c|c|}
\hline Patient & $\begin{array}{l}\text { Age/Sex at } \\
\text { FLAG-IDA ad- } \\
\text { ministration } \\
\text { (year) }\end{array}$ & Diagnosis & $\begin{array}{c}\text { Duration of } \\
\text { first remission }\end{array}$ & $\begin{array}{l}\text { Response to } \\
\text { FLAG-IDA }\end{array}$ & $\begin{array}{c}\text { Overall } \\
\text { survival/Outcome }\end{array}$ \\
\hline 11 & $16 / \mathrm{M}$ & $\begin{array}{l}\text { CALLA }(+) \text { B } \\
\text { cell ALL/third } \\
\text { relapse }\end{array}$ & - & $\begin{array}{l}\text { 1st FLAG-IDA: } \\
\text { No response }\end{array}$ & $\begin{array}{l}1 \text { months/expired } \\
\text { with infection }\end{array}$ \\
\hline 12 & $8 / \mathrm{M}$ & $\begin{array}{l}\text { AML-M2/first } \\
\text { relapse }\end{array}$ & - & $\begin{array}{l}\text { 1st FLAG-IDA: } \\
\text { No response } \\
\text { 2nd FLAG-IDA: } \\
\text { No response }\end{array}$ & $\begin{array}{l}6 \text { months/expired } \\
\text { with infection }\end{array}$ \\
\hline \multirow[t]{2}{*}{13} & $17 / \mathrm{M}$ & $\begin{array}{l}\text { CALLA }(+) \text { B } \\
\text { cell } \\
\text { ALL/second } \\
\text { relapse }\end{array}$ & 46 months & $\begin{array}{l}\text { 1st FLAG-IDA: } \\
\text { CR }\end{array}$ & $\begin{array}{l}48 \text { months/expired } \\
\text { with relapse }\end{array}$ \\
\hline & & & & $\begin{array}{l}\text { 2nd FLAG: CR } \\
\text { (consolida- } \\
\text { tion) } \\
\text { AlloHSCT } \rightarrow \\
\quad \text { relaps } \\
\text { Donor } \\
\text { lymphocyte } \\
\text { infusion }\end{array}$ & \\
\hline \multirow[t]{2}{*}{14} & $2 / \mathrm{M}$ & $\begin{array}{l}\text { CALLA }(+) \text { B } \\
\text { cell } \\
\text { ALL/refractory }\end{array}$ & - & $\begin{array}{l}\text { 1st FLAG-IDA: } \\
\text { No response }\end{array}$ & $\begin{array}{l}3 \text { months/expired } \\
\text { with infection }\end{array}$ \\
\hline & & & & $\begin{array}{l}\text { 2nd FLAG: No } \\
\text { response }\end{array}$ & \\
\hline \multirow[t]{2}{*}{15} & $15 / F$ & $\begin{array}{l}\text { AML secondary } \\
\text { to CALLA }(+) \\
\text { B cell ALL }\end{array}$ & 20 months & $\begin{array}{l}\text { 1st FLAG-IDA: } \\
\text { CR }\end{array}$ & 40 months/alive \\
\hline & & & & $\begin{array}{l}\text { 2nd FLAG-IDA: } \\
\text { CR (consolida- } \\
\text { tion) } \\
\text { AlloHSCT }\end{array}$ & \\
\hline \multirow[t]{2}{*}{16} & $2 / \mathrm{M}$ & $\begin{array}{l}\text { CALLA(+) B } \\
\text { cell } \\
\text { ALL/second } \\
\text { relapse }\end{array}$ & 3 months & $\begin{array}{l}\text { 1st FLAG-IDA: } \\
\text { CR }\end{array}$ & $\begin{array}{l}4 \text { months/expired } \\
\text { with relapse }\end{array}$ \\
\hline & & & & $\begin{array}{l}\text { 2nd FLAG-IDA: } \\
\text { CR (consolida- } \\
\text { tion) }\end{array}$ & \\
\hline 17 & $2 / \mathrm{F}$ & $\begin{array}{l}\text { AML-M2/first } \\
\text { relapse }\end{array}$ & 24 months & $\begin{array}{l}\text { 1st FLAG-IDA: } \\
\text { CR } \\
\text { 2nd FLAG-IDA: } \\
\text { CR (consolida- } \\
\text { tion) } \\
\text { AlloHSCT }\end{array}$ & 44 months/alive \\
\hline 18 & $13 / \mathrm{M}$ & $\begin{array}{l}\text { AML-M1/first } \\
\text { relapse }\end{array}$ & 10 months & $\begin{array}{l}\text { 1st FLAG-IDA: } \\
\text { CR }\end{array}$ & $\begin{array}{l}12 \text { months/expired } \\
\text { with relapse } \\
\text { ontinued on next page) }\end{array}$ \\
\hline
\end{tabular}


TABLE 2 Characteristics, Diagnosis, Response to FLAG-IDA Regimen, Overall Survival, and Outcome of the Patients (Continued)

\begin{tabular}{|c|c|c|c|c|c|}
\hline Patient & $\begin{array}{l}\text { Age/Sex at } \\
\text { FLAG-IDA ad- } \\
\text { ministration } \\
\text { (year) }\end{array}$ & Diagnosis & $\begin{array}{l}\text { Duration of } \\
\text { first remission }\end{array}$ & $\begin{array}{l}\text { Response to } \\
\text { FLAG-IDA }\end{array}$ & $\begin{array}{c}\text { Overall } \\
\text { survival/Outcome }\end{array}$ \\
\hline & & & & $\begin{array}{l}\text { 2nd FLAG-IDA: } \\
\text { CR (consolida- } \\
\text { tion) }\end{array}$ & \\
\hline \multirow[t]{3}{*}{19} & $11 / \mathrm{F}$ & $\begin{array}{l}\text { AML-M5/first } \\
\text { relapse }\end{array}$ & 7 months & 1st FLAG: CR & $\begin{array}{l}9 \text { months/expired } \\
\text { with relapse }\end{array}$ \\
\hline & & & & $\begin{array}{l}\text { 2nd FLAG: CR } \\
\text { (consolida- } \\
\text { tion) }\end{array}$ & \\
\hline & & & & AlloHSCT & \\
\hline \multirow[t]{3}{*}{20} & $13 / \mathrm{M}$ & $\begin{array}{l}\text { AML- } \\
\text { M0/refractory }\end{array}$ & 26 months & $\begin{array}{l}\text { 1st FLAG-IDA: } \\
\text { CR }\end{array}$ & 46 months/alive \\
\hline & & & & $\begin{array}{l}\text { 2nd FLAG-IDA: } \\
\text { CR (consolida- } \\
\text { tion) }\end{array}$ & \\
\hline & & & & AlloHSCT & \\
\hline \multirow[t]{2}{*}{21} & $16 / \mathrm{M}$ & $\begin{array}{l}\text { CALLA(+) B } \\
\text { cell } \\
\text { ALL/second } \\
\text { relapse }\end{array}$ & - & $\begin{array}{l}\text { 1st FLAG-IDA: } \\
\text { No response }\end{array}$ & $\begin{array}{l}3 \text { months/expired } \\
\text { with infection }\end{array}$ \\
\hline & & & & $\begin{array}{l}\text { 2nd FLAG-IDA: } \\
\text { No response }\end{array}$ & \\
\hline \multirow[t]{2}{*}{22} & $2 / \mathrm{F}$ & $\begin{array}{l}\text { AML-M2/first } \\
\text { relapse }\end{array}$ & 5 months & $\begin{array}{l}\text { 1st FLAG-IDA: } \\
\text { CR }\end{array}$ & $\begin{array}{l}6 \text { months/expired } \\
\text { with relapse }\end{array}$ \\
\hline & & & & $\begin{array}{l}\text { 2nd FLAG-IDA: } \\
\text { CR (consolida- } \\
\text { tion) }\end{array}$ & \\
\hline 23 & $12 / \mathrm{F}$ & $\begin{array}{l}\text { AML secondary } \\
\text { to CALLA }(+) \\
\text { B cell ALL }\end{array}$ & - & $\begin{array}{l}\text { 1st FLAG-IDA: } \\
\text { No response }\end{array}$ & $\begin{array}{l}2 \text { months/expired } \\
\text { with infection }\end{array}$ \\
\hline \multirow[t]{2}{*}{24} & $15 / F$ & $\begin{array}{l}\text { AML secondary } \\
\text { to CALLA }(+) \\
\text { B cell ALL }\end{array}$ & 5 months & $\begin{array}{l}\text { 1st FLAG-IDA: } \\
\text { CR }\end{array}$ & $\begin{array}{l}6 \text { months/expired } \\
\text { with relapse }\end{array}$ \\
\hline & & & & $\begin{array}{l}\text { 2nd FLAG-IDA: } \\
\text { CR (consolida- } \\
\text { tion) }\end{array}$ & \\
\hline \multirow[t]{3}{*}{25} & $8 / \mathrm{F}$ & $\begin{array}{l}\text { AML secondary } \\
\text { to CALLA }(+) \\
\text { B cell ALL }\end{array}$ & 20 months & $\begin{array}{l}\text { 1st FLAG-IDA: } \\
\text { CR }\end{array}$ & 40 months/alive \\
\hline & & & & $\begin{array}{l}\text { 2nd FLAG-IDA: } \\
\text { CR (consolida- } \\
\text { tion) }\end{array}$ & \\
\hline & & & & AlloHSCT & \\
\hline
\end{tabular}

Note $. \mathrm{CR}=$ complete remission; $\mathrm{PR}=$ partial remission; $\mathrm{ALL}=$ acute lymphoblastic leukemia; $\mathrm{AML}=$ acute myeloblastic leukemia; MDS = myelodysplastic syndrome; AlloHSCT $=$ allogeneic hematopoietic stem cell transplantation. 
toxicity. Five children had a transient increase in hepatic transaminases and none of the children had hyperbilirubinemia. Nausea and vomiting were controlled with antiemetics. Cardiotoxicity was observed in $9(36.0 \%)$ children on echocardiography. The mean value of left ventricle EF of the children with cardiotoxicity was $51.0 \% \pm 9.8 \%(41.0-57.0 \%)$ after the first cycle of the FLAG-IDA regimen. During the follow-up, $23(92.0 \%)$ children had mucositis (32\% grade III/IV mucositis), $8(32.0 \%)$ had pulmonary fungal infections (probable fungal infection), 23 (92.0\%) had febrile neutropenia, and $6(24 \%)$ had documented infections. The isolated organisms in blood cultures included Serratia marcescens, Staphylococcus aureus, Staphylococcus epidermidis, Staphylococcus auricularis, Escherichia coli, and Pseudomonas aeruginosa. Thorax computerized tomography (CT) of the children with fungal infections revealed pulmonary nodules. The specific agents were not isolated and preemptive antifungal treatment was started based on tomography findings.

\section{Overall Survival}

Allogeneic HSCT was performed in $10(40 \%)$ patients who had HLA $6 / 6$ identical sibling donors. However, 5 patients who underwent allogeneic HSCT were lost due to infection $(n=1)$ or relapse of the primary disease $(n=4)$. One patient (Case 3$)$ had relapse of the primary disease after allogeneic HSCT and she received FLAG regimen after the transplantation. The other 9 children received FLAG-IDA or FLAG regimen to achieve remission state before transplantation. The overall survival of patients who underwent allogeneic HSCT (mean: 40.6 \pm 4.7, median: 40, range: 34-46 months) was longer than that of patients (mean: $5.5 \pm 4.3$, median: 4 , range: 1-15 months) who did not. (All of the survivors were AML and underwent HSCT.)

Thus, after FLAG-IDA or FLAG regimen, 5 (20.0\%) children were alive and $20(80.0 \%)$ children were lost due to infection or relapse of the primary diseases. Only 2 children (Cases 6 and 11) were lost with infection before marrow recovery. Of those 5 children who are alive, all underwent allogeneic HSCT and are still in remission. The overall survival of the 25 patients was $28.6 \pm 17.7$ months (median: 36 , range: $2-48$ months).

\section{DISCUSSION}

Children with refractory and relapsed leukemia, as well as children with a secondary AML, have a poor prognosis, and alternative induction therapies to achieve repeat remission are very limited [8, 9]. High-dose Ara-C is one of the most effective drugs in reinduction therapy of poor-prognosis acute leukemia, and fludarabine applied prior to Ara-C increases the Ara-CTP accumulation in the blast cells. Furthermore, high-dose Ara-C acts synergistically with fludarabine, anthracyclines, and G-CSF. On the basis of this 
information, fludarabine and high-dose Ara-C with or without G-CSF were used in poor-prognosis adult AML cases and produced CR rates of $50 \%$ to $60 \%$ [10-12]. After the initial usage of fludarabine and high-dose Ara-C, IDA was added to this combination chemotherapy. That application increased the CR rate to $67 \%$ to $80 \%$ in pediatric cases with refractory or relapsed AML $[12,13]$. The number of studies in which the FLAG-IDA regimen has been used in children with poor-prognosis acute leukemia, especially in ALL, is very limited [1-3, 13-15]. In this study, we aimed to evaluate the CR rate, toxicity, and overall survival of children with poor-prognosis acute leukemia who received the FLAG-IDA regimen in our center.

In a study conducted by Fleischhack et al [2], the FLAG-IDA regimen was administered to children with refractory, relapsed, or secondary AML (age range: $1.2-17.5$ years), and 17/23 (73.9\%) children achieved a CR with a median duration of 13.5 months; 9 (39.1\%) children remained in continuous CR with a median duration of 17.5 months. Of these 23 children, $11(47.8 \%)$ underwent bone marrow transplantation (BMT) or peripheral blood SCT. In their series, most of the children $(17 / 23,73.9 \%)$ were on the first relapse; there were no cases of post-BMT relapse, and only 1 child was secondary AML. However, in our series, there were only $8(32.0 \%)$ children who were on the first relapse. Additionally, there were 5 secondary AML cases and 1 post-BMT relapse case, which have extremely poor prognosis.

McCarthy et al [15] preferred FLAG without anthracyclines in heavily pretreated children, and 13/16 (70\%) children achieved CR in that study. Thirteen $(70 \%)$ patients underwent BMT, and 7 (43.8\%) patients were alive 12 months after the FLAG regimen. The rate of patients who underwent BMT was higher than that of our series, and this might explain the increased number of patients who were alive.

Yalman et al [3] from Turkey used the FLAG-IDA regimen in 17 children (age range: 3-18 years) with relapsed acute leukemia or chronic leukemia with acute blastic crisis. They reported that only $3 / 17(17.6 \%)$ children achieved CR and 1/17 (5.9\%) was disease-free in the 30th month of the second remission. The only surviving child also had donor lymphocyte infusion (DLI) on the 7th day of the second FLAG-IDA course. Seven of 25 courses resulted in fatal infections. In that study, induction failure was high and the outcome was disappointing. They concluded that the FLAG-IDA regimen was not a cost-effective therapy in a developing country. In our study, after all cycles of FLAG-IDA or FLAG regimen, $60.0 \%$ of children showed CR. Identical dosing and schedule of Flu, Ara-C, and G-CSF was used in all patients in our series. Only 2 children (Cases 6 and 11) were lost with infection before marrow recovery. Although our patients carried very poor risk criteria, the overall response rate was acceptable. Yalman et al's paper was written in 2000, during that period the supportive care possibilities might have been limited in Turkey. We still suggest that the FLAG-IDA regimen can be attempted in children with poor-prognosis acute leukemia in Turkey. 
Fleischhack et al [2] observed cardiac toxicity in 3 of 24 (12.5\%) FLAGIDA courses. Nine children $(9 / 17,52.9 \%)$ had pulmonary involvement and $2(2 / 17,11.8 \%)$ were suspected to have fungal infections in that study. In our series, cardiotoxicity was observed in 9/25 (36.0\%) children on echocardiography, and these 9 children received the second cycles of the regimen as FLAG, without IDA. A mild or asymptomatic decrease in left ventricle EF was observed in these children and none developed congestive heart failure. Additionally, on the follow-up echocardiographic evaluation, the decrease in left ventricle EF was improved. During the follow-up, $8(32.0 \%)$ children had pulmonary fungal infections. Mucositis and febrile neutropenia were other toxic side effects of the regimen observed in our series. Long-term neutropenia, toxic injury of the lung epithelial cells by cytotoxic drugs, and long-term T-helper cell depletion produced by fludarabine are among the causes of infectious complications, including pulmonary fungal infections, mucositis, and febrile neutropenia $[16,17]$. In our series, only 2 courses resulted in fatal infections (both fungal infections) before marrow recovery, and we thus consider the toxicity of the FLAG-IDA regimen to be acceptable for children with poor-prognosis acute leukemia.

In conclusion, the complete remission rate using the FLAG-IDA regimen was quite high in the present study, and we thus suggest that this regimen is a possible option, especially prior to allogeneic HSCT, in children with poor-prognosis acute leukemia.

Declaration of Interest: The authors report no conflicts of interest. The authors alone are responsible for the content and writing of the paper.

\section{REFERENCES}

[1] Fleischhack G, Graf N, Hasan C, et al. [IDA-FLAG (idarubicin, fludarabine, high dosage cytarabine and G-CSF) - an effective therapy regimen in treatment of recurrent acute myelocytic leukemia in children and adolescents. Initial results of a pilot study]. Klin Padiatr. 1996;208:229-235.

[2] Fleischhack G, Hasan C, Graf N, et al. IDA-FLAG (idarubicin, fludarabine, cytarabine, G-CSF), an effective remission-induction therapy for poor-prognosis AML of childhood prior to allogeneic or autologous bone marrow transplantation: experiences of a phase II trial. Br J Haematol. 1998;102:647-655.

[3] Yalman N, Sarper N, Devecioğlu O, et al. Fludarabine, cytarabine, G-CSF and idarubicin (FLAG-IDA) for the treatment of relapsed or poor risk childhood acute leukemia. Turk JPediatr. 2000;42:198-204.

[4] Gandhi V, Estey E, Keating MJ, et al. Fludarabine potentiates metabolism of cytarabine in patients with acute myelogenous leukemia during therapy. J Clin Oncol. 1993;11:116-124.

[5] Huhmann IM, Watzke HH, Geissler K, et al. FLAG (fludarabine, cytosine arabinoside, G-CSF) for refractory and relapsed acute myeloid leukemia. Ann Hematol. 1996;73:265-271.

[6] Ferrara F, Palmieri S, Pocali B, et al. De novo acute myeloid leukemia with multilineage dysplasia: treatment results and prognostic evaluation from a series of 44 patients treated with fludarabine, cytarabine and G-CSF (FLAG). Eur J Haematol. 2002;68:203-209.

[7] National Cancer Institute. Common Toxicity Criteria. Available at: http://www.ucdmc.ucdavis.edu/ clinicaltrials/documents/NCI_toxicity_table.pdf. Accessed 27 July 2010.

[8] Kantarjian HM, Estey EH, Keating MJ. Treatment of therapy-related leukemia and myelodysplastic syndrome. Hematol Oncol Clin North Am. 1993;7:81-107. 
[9] Stahnke K, Ritter J, Schellong G, et al. [Treatment of recurrence of acute myeloid leukemia in childhood. A retrospective analysis of recurrence in the AML-BFM-83 study]. Klin Padiatr. 1992;204:253-257.

[10] Estey E, Thall P, Andreeff M, et al. Use of granulocyte colony-stimulating factor before, during, and after fludarabine plus cytarabine induction therapy of newly diagnosed acute myelogenous leukemia or myelodysplastic syndromes: comparison with fludarabine plus cytarabine without granulocyte colony-stimulating factor. J Clin Oncol. 1994;12:671-678.

[11] Visani G, Tosi P, Zinzani PL, et al. FLAG (fludarabine + high-dose cytarabine + G-CSF): an effective and tolerable protocol for the treatment of 'poor risk' acute myeloid leukemias. Leukemia. 1994;8:1842-1846.

[12] Jackson G, Taylor P, Smith GM, et al. A multicentre, open, non-comparative phase II study of a combination of fludarabine phosphate, cytarabine and granulocyte colony-stimulating factor in relapsed and refractory acute myeloid leukaemia and de novo refractory anaemia with excess of blasts in transformation. BrJ Haematol. 2001;112:127-137.

[13] Dinndorf PA, Avramis VI, Wiersma S, et al. Phase I/II study of idarubicin given with continuous infusion fludarabine followed by continuous infusion cytarabine in children with acute leukemia: a report from the Children's Cancer Group. J Clin Oncol. 1997;15:2780-2785.

[14] Leahey A, Kelly K, Rorke LB, et al. A phase I/II study of idarubicin (Ida) with continuous infusion fludarabine (F-ara-A) and cytarabine (ara-C) for refractory or recurrent pediatric acute myeloid leukemia (AML). J Pediatr Hematol Oncol. 1997;19:304-308.

[15] McCarthy AJ, Pitcher LA, Hann IM, et al. FLAG (fludarabine, high-dose cytarabine, and G-CSF) for refractory and high-risk relapsed acute leukemia in children. Med Pediatr Oncol. 1999;32:411-415.

[16] Anderlini P, Luna M, Kantarjian HM, et al. Causes of initial remission induction failure in patients with acute myeloid leukemia and myelodysplastic syndromes. Leukemia. 1996;10:600-608.

[17] Goodman ER, Fiedor PS, Fein S, et al. Fludarabine phosphate: a DNA synthesis inhibitor with potent immunosuppressive activity and minimal clinical toxicity. Am Surg. 1996;62:435-442. 